\title{
WHY FISCALLY ENCOURAGE PHILANTHROPY?
}

\section{Analyzing discourses and issues of political actors who legislate on philanthropy in Switzerland}

\author{
Caroline Honegger, Romain Carnac, Philip Balsiger \\ and Alexandre Lambelet
}

\section{Introduction $^{1}$}

Philanthropy, that is, the giving of money (or time) for public purposes, is often co-financed by public authorities through tax exemptions to the benefit of public utility organizations and donors. Philanthropy is thus not only a social practice but also as a public policy tool (Steinmo, 1986; McDaniel, 1989; Salamon, 1989; Howard, 1993) whose development and support by public authorities has been the subject of much controversy (Brilliant, 2000; McGravie, 2003; Reich, 2018; Zunz, 2011). Studies have shown that the institutional underpinnings of philanthropy vary depending on different non-profit regimes (Salamon and Anheiner, 1998; Salamon and Toepler, 2000; Layton, 2015); at the same time, a trend towards increased public and fiscal encouragement of philanthropy has been observed in many countries (Lambelet, 2014).

Charities and their advocates agree on the importance of fiscal incentives to promote donations (Bekkers and Wiepking, 2011; Layton, 2015), but there are vivid debates about the economic effectiveness of incentives and their legitimacy from a democratic point of view (OECD, 2020). Many studies, in particular by economists, have analyzed whether tax exemptions are more or less efficient than direct subsidies and whether fiscal incentives crowd out other forms of giving (Ariely, Bracha and Meier, 2009; Bakija and Heim, 2011; Lideikyte Huber, 2020; Monnet and Panizza, 2017). Other authors have discussed tax exemptions' legitimacy in terms of justice, revealing the problem of the potential nonalignment between the beneficiaries of donations and the goals of public policies (McDaniel, 1989), as well as the effects that tax exemptions may have on the democratic functioning of countries, in particular because of the plutocratic bias linked to exemption systems (Thaler, 2010; Reich, Cordelli and Bernholz, 2016; Leat, 2016; Reich, 2018; Saez and Zucman, 2019; Cagé, 2020).

Yet while political philosophers have discussed the possible justifications or rationales of fiscal incentives for philanthropy and philanthropic giving (Benshalom, 2008; Reich, 2018), there are 
few empirical studies looking at how political actors justify the use of fiscal tools to encourage philanthropy. How do they conceive of the role of philanthropy, and what arguments do they use to justify the legal and tax treatment that governs it? Taking Switzerland as a case study, this chapter opens this 'black box' in order to know more about the motivational dynamics of increasing (or not) tax expenditures for charitable giving and volunteering and widening the boundaries of what is recognized as being of public interest and should benefit from tax incentives. Since political actors are the ones who make the legislation that governs philanthropic practices and decide on the tax exemptions from which these organizations and donations may or may not benefit, it is crucial to question these actors in order to understand the place of philanthropy today.

Through a qualitative study of 48 interviews with Swiss political actors (parliamentarians and members of cantonal executive bodies), the chapter analyzes how these actors problematize philanthropy ${ }^{2}$ and decide on the legislative developments that should frame it. Switzerland's non-profit regime can be characterized as 'liberal' (Helmig et al., 2017) or as between a liberal and social-democratic model (Schnurbein and Perez, 2018), with a large third sector, large subsidies from public authorities (Helmig, Lichtsteiner and Gmür, 2010), deductible donations for donors and a broad eligibility for organizations (Lideikyte Huber, 2018). ${ }^{3}$ In comparison with other countries (European Foundation Center, 2015), not all non-profit organizations are tax exempt and can benefit from tax-deductible donations: Sports clubs or self-help organizations are excluded. And although philanthropic organizations have to be registered officially, no further public reporting obligations exist. Since the early 2000 s, there have been a few important reform proposals, most aiming at further liberalization (to broaden the type of organizations that can benefit from the recognition of public utility, to fiscally support volunteering or to increase tax incentives for donations) but some also seeking to increase the transparency of philanthropic organizations. In this context of a liberal regime, we found that to speak about the fiscal encouragement of philanthropy, political actors' reasons for supporting philanthropy are diverse and refer to very different realities of philanthropic organizations. The analysis identifies five ways of framing philanthropy: civic, liberal, pragmatic, wary and critical. We also see, however, that while political actors draw on different rationales and frame the issue differently, arguments related to the efficiency of philanthropic giving are most commonly used to justify fiscal incentives.

The next two sections detail the theoretical framework and the methodological approach used in this chapter. The following empirical part proceeds in two steps: A first part presents the arguments used by political actors and groups them into four rationales they refer to. A second part analyzes the interviews to develop a typology of five frames Swiss political actors use when speaking about philanthropy and tax exemptions. Because we have observed that these frames are linked with the experiences of the third sector the political actors have, we will discuss the link between their way of framing the issue and the positions they have in the third sector and as political actors.

\section{Conceptual framework: rationales, frames and arguments}

Approaches on philanthropy by political philosophers have shown different rationales, that is to say 'higher common principles,' that can be viewed as ensembles of higher-order meanings people (including political actors) have to deal with (for example, in a democracy: liberty or equality). In his theoretical and philosophical work on philanthropy, Benshalom (2008) 
identifies two rationales for the deductibility of donations: 1) they encourage more and/or better spending of public goods; 2) they are desirable because they allow taxpayers to 'vote with their dollars' and to express their preferences regarding the allocation of public goods in society. More recently, Reich $(2013,2018)$ distinguished three rationales: 1) a 'tax base rationale' that stems from the principle that donations for public-interest organizations are voluntary means of giving up part of one's income for the public good. Consequently, this donation should not be taxed. 2) An 'efficiency rationale' based on the idea that the state can encourage philanthropic activity in order to stimulate the production of collective goods of greater social value than those that the state alone can produce. 3) A 'pluralism rationale'; In this argument, the tax exemption is justified by its role in the promotion of a diversified, pluralist and decentralized third sector, the basis of a liberal democracy. This argument also contends that pluralism, while decentralizing political decision-making, also favors the emergence of new and innovative solutions.

These rationales are interesting for understanding the kind of conceptual debates in which philanthropy is caught. But they tell us little about how political actors respond concretely to proposals for legislative or tax changes that surround the issue of philanthropy. Coming out of theoretical debates, this chapter goes one step further to study the concrete frames the political actors who make the laws governing philanthropy use. Following a constructivist approach in the field of social problems research, we want to study, in this chapter, the more specific frames (Goffman, 1974; Gamson and Modigliani, 1989; Reese, Gandy and Grant, 2001) political actors use concretely when they have to speak on philanthropy. Frames are articulations of arguments that can be drawn from the different rationales and that shape the meaning individuals give to the problems they face. Frames can be linked with rationales, but it is the arrangement or hierarchy of the elements drawn from the latter that makes different frames specific and that promote particular definitions of legitimacy or conceptions of the common good. If the frames are different from the rationales identified by political philosophy works, it is because, for political actors, philanthropy does not exist outside - or is not thought of independently of - particular conceptions of the state, taxation or the functioning of democracy. They do not think of philanthropy as an isolated phenomenon but read philanthropy together with other questions that also involve the place of the state or the equality between citizens.

We thus have to look at the arguments used by the political actors during the interviews, at the pros and cons of tax incentives in favor of philanthropy or the pros and cons of the enlargement of the type of organizations that can benefit from them. Doing so, we use an inductive approach to identify the rationales political actors rely on in their arguments. We then study how political actors combine different arguments and standards of evaluation in order to produce frames. Constructivist approaches in the field of social problems research have shown how different actors frame problems and public policies in different ways (Best, 2008). We see frames as a 'central organizing idea (. . .) for making sense of relevant events, suggesting what is at issue' (Gamson and Modigliani, 1989, p. 3). They are at the center of 'interpretative packages' that 'give meaning to an issue' (ibid.). In other words, frames as interpretative packages combine different elements - arguments referring to different rationales, representations of the respective role of the state and civil society, views of the policy-making process, conceptions of the public interest, and so on - in a specific way. Using this type of analysis, our goal is to uncover the different interpretative packages underlying discourses on philanthropy in a liberal welfare state like Switzerland. 


\section{Methods and data}

Using the term 'public utility' in the search engines of the parliaments at the federal level and in three cantons, ${ }^{4}$ we have listed the proposals for reform of tax exemptions for philanthropy over the period from 2000 until 2018, that is, 39 interventions at the federal level and the same number at the cantonal level for the three cantons. They concern themes as varied as the thresholds of deductibility of donations to philanthropic organizations, the calling into question of fiscal advantages for major sports federations, the opportunity to permit volunteers to enjoy tax reductions, the improvement of Switzerland's attractiveness in the sector of philanthropy, the recognition of the public interest of cultural organizations or of political parties, the possibility of spreading an exceptional donation over a number of fiscal years and the fight against tax fraud and money laundering in non-governmental organizations. Since these themes have a common denominator of questioning the definition of philanthropy and the fiscal and legal framework from which it must benefit, debates on these different parliamentary objects were incorporated into the body of the research.

On the basis of this data, we identified the political actors who played a leading role, either because they made an intervention or participated significantly in political debates or because, at this point in time, they occupied a key position (president or vice-president of the tax commission, state councilor in charge of the Department of Finance, etc.). Of the 88 individuals thus identified, 48 responded favorably to our interview request. They belong to different bodies, political formations and cantons. With these political actors, we conducted semi-directive interviews, following a single grid, for a period of time ranging from 40 minutes to 3 hours. In the grid, we focused on discussing the intervention they were involved in and asked more general questions about philanthropy and tax exemption policies. In a first step, we used content analysis (Krippendorf, 2004) to list all the arguments given in favor of or against tax exemptions. We then analyzed this list to identify what underlying rationales they build upon. This led us to class them into four groups. In a second step, we analyzed the interviews internally and in comparison with each other to characterize the way each interviewee frames philanthropy. In this step, we intersected discursive data on arguments and opinions given by interviewees with elements objectifying their personal trajectories and political, professional and community engagements. This led us to the development of a typology around five interpretative frames, related to different views of philanthropy.

\section{Arguments for and against tax incentives for philanthropy: underlying rationales}

Interviewing political actors on the theme of tax incentives for philanthropy first led to astonishment at the great diversity of their remarks: Not only do their positions and arguments differ, but they rarely speak about the same object. Nonetheless, there are some recurring themes in the discourse. The systematic coding of the interview transcripts allowed us to extract argument types which point at four distinct categories. Each of these categories evaluates the tax measures supporting philanthropy in light of a different rationale: The first category assesses the measures discussed from the point of view of (fiscal) justice, the second evaluates their efficiency, the third takes democracy as a frame of reference and the last judges them through the prism of virtue. The left side of Figure 2.1 lists the arguments identified and the rationale they refer to. For each of these categories, we illustrate the layout of themes and arguments, with an emphasis on some salient tendencies amongst the interviews. 


\section{Justice}

The donation is another way to pay one's taxes: through directly supporting social goods that the state will not be financing.

The normal taxation system is 'confiscatory'; unfair; anything that allows one to ease the burden is good.

Deductions are not fair because they advantage certain taxpayers (the more fortunate ones).

Deductions may be diverted from their original purpose and used as an instrument of fiscal optimizations.

\section{Efficiency}

It is in the state's interest to maximize the volume of donations to philanthropic organizations/one has to look for the money where it can be found.

Incentives are effective in increasing the number and the size of donations.

Philanthropic organizations are less expensive than state services in certain domains, especially thanks to volunteer work.

Philanthropic organizations are more effective, more reactive, closer to the grassroots than state services in certain domains.

The state, on its own, lacks the means to provide all the public and social services desired.

It is necessary to put forward a system of advantageous tax deductions to be more attractive than rival cantons/countries.

Certain social problems cannot be resolved by philanthropy since they are not very visible or evoke little sympathy.

Tax deductions tend to aggravate inequalities in preventing redistribution.

Deductions generate major fiscal losses; they empty state coffers.

\section{Virtue}

It is fair that those who give to good causes be recompensed/thanked by the collectivity.

The role of the state is to recognize, highlight and recompense virtuous behavior.

A donation is never disinterested; one always receives in return psychological, symbolic or social gratification.

It is immoral or antisocial to not pay taxes; the principle of universality of taxation is symbolically important and must be respected.

\section{Democracy}

The tax incentive is a means to support the dynamism of the third sector/civil society/private initiatives, which are good in themselves.

The deductibility of donations gives decision-making power to citizens, who 'vote for projects'; this is a mechanism of direct democracy.

It is not desirable that the state concentrate all the decision-making power and means of implementing social policies in its own hands.

Philanthropic organizations escape democratic control; their actions are not controlled or are insufficiently controlled by political authorities.

Figure 2.1 Collection of arguments according to rationales and types of framing 
Why fiscally encourage philanthropy?

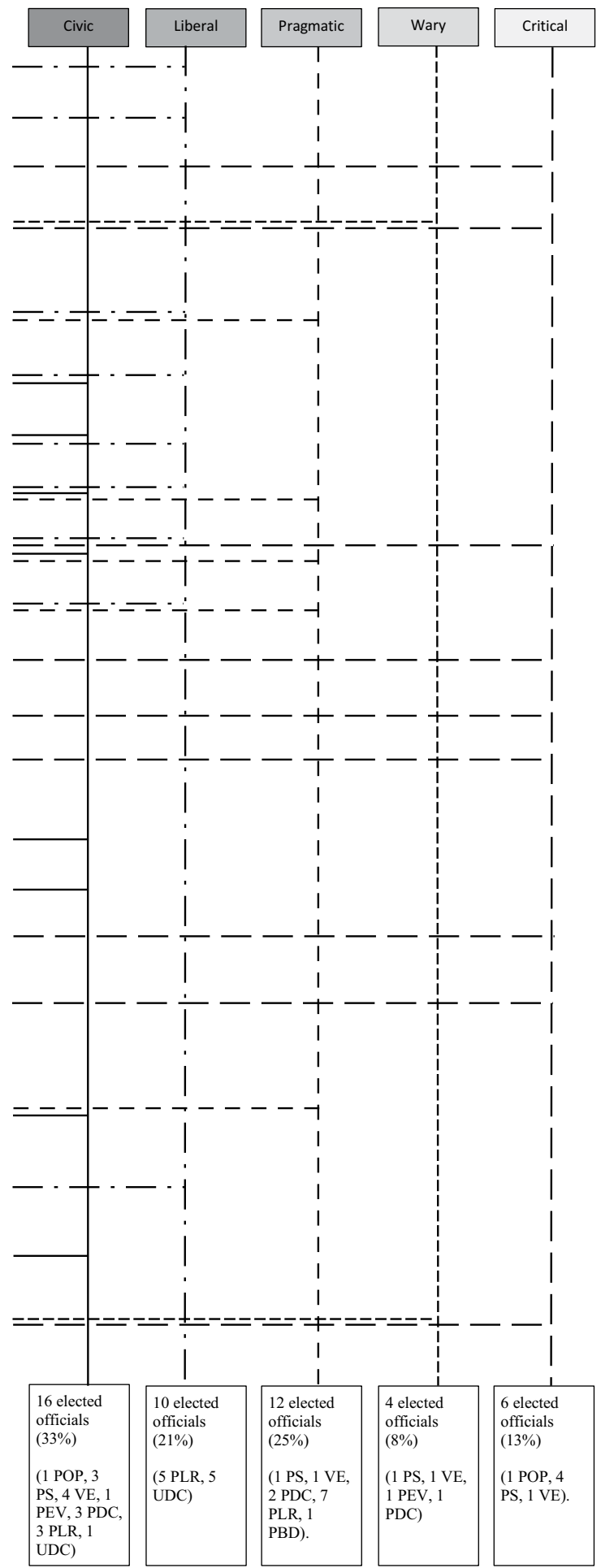

Figure 2.1 Continued 


\section{Justice}

The tax exemption for philanthropy is generally presented as obvious by Swiss politicians: 'it would be "completely absurd and . . scandalous to work not for profit and then have to pay taxes' (Interviewee 28, VE). ${ }^{5}$ Similarly, it would be unfair to pay taxes on money which one had given away: 'the people who give this away no longer have this money in their own bag' (Interviewee 42, PEV). This perspective, which comes back to what Reich (2013) calls 'tax-base rationale', considers that, for the donation affecting the tax base, the latter must be calculated after the donation and not before. Finally, the donation often seems like another means of paying one's taxes, since one is financing social goods that the state will not then have to finance. Therefore, the focus is the equitable treatment of the donor; it would not be fair to make someone pay tax on a sum of money given to a public-interest organization.

The rationale of fiscal justice as it appears in the Swiss political discourse contains further arguments: For instance, some politicians see tax incentives for philanthropy simply as a means of providing tax relief: 'the more we can lower it, the better' (Interviewee 18, PLR) and 'the state's appetite for taxes is exaggerated' (Interviewee 31, UDC). Other politicians use arguments referring to fiscal justice to criticize fiscal advantages. To them, deductions are an instrument of fiscal optimization, and the donation becomes 'a means to avoid taxes,' especially for the 'ultrarich' (Interviewee 29, PDC). Some politicians also emphasize that the risk of creating unfair situations is increased by the fact that deductions, due to the role of progressive tax rates, benefit the wealthiest taxpayers more.

\section{Efficiency}

The second rationale identified roughly overlaps with what Reich calls 'subsidy rationale'. Here, the idea is that the state encourages philanthropic activity in order to stimulate the production of a collective good of greater social value than if the state alone had done this. The encouragement is thus effective in promoting the public good; what matters is the impact of the donation. This argument is part of the classic critique of government, especially advanced by proponents of new public management, who see the public sector as being slow, bureaucratic and unresponsive to the needs of its beneficiaries, as opposed to the private sector, which is closer to the people, more reactive and more results oriented.

The efficiency rationale as it appears in the Swiss political discourse on philanthropic organizations covers a wide range of arguments, which all converge on the objective of maximizing the quantity and quality of services delivered for the least possible cost to the state. Efficiency refers to two different notions (Monnet and Panizza, 2017): treasury efficiency (purely from a budgetary perspective, measured by comparing the amounts foregone by the public treasury due to deductions and the amounts of donations to public-interest organizations due to this fiscal encouragement) and social efficiency (which cross-references the loss of fiscal tax revenues for the state, the quality of social goods produced and the cost to the state if it had had to produce them). These two dimensions of efficiency can be found in the discourse of political actors: Thus, one can distinguish, on the one hand, the arguments which proceed from a budgetary rationale and those which relate to the effectiveness of tax incentives in financing public-interest organizations and, on the other hand, those bearing on the efficiency of these organizations themselves, that is, their capacity to deliver more and better services than the state could provide, at a fixed cost.

Arguments referring to efficiency are also used by Swiss politicians to criticize tax incentives for philanthropy. Some of them highlight the fact that certain social problems cannot be 
resolved by philanthropy since they are not very visible or evoke little sympathy, while others emphasize the fiscal losses generated by tax deductions and the negative consequences for the state budget. Another critique expressed by Swiss politicians refers to the fact that tax deductions tend to aggravate inequalities by preventing redistribution.

\section{Democracy}

The third rationale identified, that of democracy, also covers arguments in favor of tax incentives for philanthropy and criticisms of this measure. It corresponds approximately with what Reich calls 'pluralism rationale'. In this argument, the tax exemption is justified by its role in the promotion of a diversified, pluralist and decentralized third sector, the basis of a liberal democracy. This argument also contends that by decentralizing political decision-making, one favors the emergence of new and innovative solutions. However, democracy is also used as an argument by some politicians to contest the fiscal encouragement of philanthropy. The third sector is denounced as escaping the control of political authorities and therefore of democracy. Through the mechanism of tax relief, the sector's financing escapes the 'political, public and democratic realm' (Interviewee 40, PS) and 'the state loses control of its public policy' (Interviewee 47, PS).

This phenomenon is reinforced by the lack of transparency, the activity of foundations being described at times as 'completely opaque' (Interviewee 9, POP), and by the 'lobbying' (Interviewee 45, PS) of the sector of foundations which contributes to removing even more democratic control. ${ }^{6}$ Finally, in 'permitting people or entities with the means to not contribute to the common pot' (Interviewee 40, PS) to 'circumvent the state . . . in deciding themselves where to put their dough' (Interviewee 47, PS), it is the very democratic culture itself which is threatened: The risk is then that of seeing a form of 'individual democracy' emerge (Interviewee 40, PS) which would reject the redistributive dimension of taxes.

\section{Virtue}

In addition to the three rationales identified by Reich, a fourth category of argumentation referring to the principle of virtue appeared in the discourse of Swiss political actors on philanthropic activities. A priori, philanthropic activity usually plays a very positive role in moral terms, and the political actors interviewed do not really disagree with this widely held view. Public-interest efforts are often defined as 'helping people' (Interviewee 5, VE) and are linked to the idea of 'gift of self' (Interviewee 3, PDC). Some people base this on 'Christian values' (Interviewees 30, PLR, and 36, VE) and others more generally on the 'concern for other people' (Interviewee 33, PS). From this perspective, which takes moral evaluation of the 'altruistic' commitment as its point of departure, plans for tax relief for philanthropy are defended as a means to highlight those who do good, whether public interest organizations, generous donors or volunteers.

Thus, the fact that philanthropic activity is considered virtuous justifies it being 'treated in a special way' (Interviewee 39, PDC) by the state. The donation of money to public-interest organizations is perceived as an integral part of this philanthropic activity. Unlike taxes, which constitute an obligatory contribution to the common good, the donation is part of an interpersonal' relation (Interviewee 25, PDC). 'There is a stronger human gesture which is not at all anonymous' (Interviewee 36, VE).

Another virtue of the donation is also related to what it gives the donor: 'The donation benefits the recipient, in addition to the one who gives' (Interviewee 36, VE). This holds true, too, for the donation of time. One political actor, smiling, refers to 'a study which shows that 
the more volunteer work you do, the happier you are in life' (Interviewee 30, PLR). Yet many political actors deplore the fact that awareness of the mutual advantage of altruistic commitment has tended to fade away. The prevailing perception of those interviewed is that we are living 'in a society where people are increasingly individualistic' (Interviewee 3, PDC). Consequently, it is necessary for the state to guide them towards the path of charitable works, and tax benefits serve this purpose. However, certain remarks made during the interviews serve to tarnish the popular image of the noble philanthropist. Thus, philanthropic organizations are accused of 'making money from the suffering of others' (Interviewee 1, PEV). As for the donation itself, it is sometimes depicted as a means of enhancing an individual's 'personal prestige' (Interviewee $37, \mathrm{VE}$ ) or of 'giving oneself a reputation as a benefactor' (Interviewee 47, PS), with the donation seen as a 'marketing' tool (Interviewee 40, PS).

Another critique, on the question of virtue, arises with regard to tax incentives for philanthropy: that it is immoral that some not pay taxes, whatever the reason. Here, indeed, the very principle of tax incentives as a tool of public policy is being criticized: 'taxation should not be jeopardized' (Interviewee 36, VE). The problem with deductions and exemptions is that they create a multitude of specific fiscal situations liable to threaten this principle of universal taxation.

\section{Five frames on philanthropy}

As the analysis so far has established, political actors refer to a wide range of arguments to express their positions for or against tax advantages for philanthropy. However, all these arguments are not drawn upon in an identical fashion in each interview; the political actors select, combine and rank-order them according to different modalities. The coding of the interviews allows us to see a structure behind this diversity: it brings out various recurring argumentative patterns, which define five types of frames on philanthropy. Their graphic representation permits us to visualize their differences (see right half of Figure 2.1) but also the basis of ideas, values and representations that they share.

The left side of Figure 2.1 classifies the arguments of political actors as presented in the first part of this chapter by rationales, in favor of fiscal advantages (bright) and opposed (dark). Each trait linking an argument to a frame signifies that this argument is employed by the majority of political actors using this frame: for example, the majority of the political actors whose discourse is 'liberal' use the first positive argument of the justice category, 'The donation is another means of paying one's taxes'. In this same category, the negative argument 'deductions may be diverted from their original purpose' is used by the majority of those whose discourse is 'wary', as well as most of those whose discourse is predominantly 'critical'.

Figure 2.1 reveals that political actors largely share a positive view of fiscal advantages for public-interest organizations: Three of the five frames are based exclusively on arguments in favor of these measures; and these three frames were employed by 38 political actors, that is, $79 \%$ of all political actors interviewed. It follows that arguments in favor of fiscal advantages are much more often employed (there are 23 uses of positive arguments, marked by horizontal lines towards the bright cases) than counterarguments (10 uses of negative arguments). Analysis of Figure 2.1 then shows an overwhelming predominance of the rationale of efficiency in political actors' discourse: out of a total of 33 uses of arguments in the five categories, more than half fall into this category. It is principally in reference to this rationale that the role and place of Swiss philanthropic organizations and the legitimacy of fiscal measures designed to support them are evaluated. Even in the discourse of political actors more critical of or even hostile to tax 
incentives for philanthropy, efficiency structures the frame of reference of their argumentation and tends to be seen as obvious.

While political actors largely approve of fiscal advantages for public-interest organizations, based particularly on efficiency arguments, they do not all do so for the same reasons. In the first type of discourse, the 'civic' frame, fiscal advantages are perceived as a means of supporting the third sector. In the 'liberal' frame, these advantages serve to reduce taxes and the ascendancy of the state, and in the 'pragmatic' frame, they represent a measure of good management of public finances rather than an option reflecting a political orientation. To these first three categories can be added two frames composed essentially of negative arguments: In the 'wary' frame, the fiscal advantages constitute a risk factor for abuse and fraud; the 'critical' frame, for its part, interprets these advantages as undermining equality (between taxpayers and between organizations). Finally, each of these frame types is distinguished by a particular view of philanthropic organizations, linking them to a specific issue. We now propose to examine them in greater detail.

\section{Fiscal policies in favor of public-interest organizations, a solution to support the dynamism of civil society: the 'civic' frame}

'Civic' discourse frames fiscal advantages for philanthropic organizations as a good way to support the third sector. Many political actors adopting this frame are thus favorable to broadening the criteria of philanthropic organizations and to raising the threshold of deductibility of donations to them. Some of those employing this discourse, however, are less enthusiastic about the idea of such increases, fearing significant losses of revenues for the state and worrying about the social injustice caused by such a measure. Therefore, a number of those interviewed, notably on the left, explain that the choice between these two options constitutes a dilemma for them.

In addition to drawing upon the category of efficiency, the 'civic' frame is primarily composed of positive arguments from the value categories of democracy and virtue. Regarding the value of democracy, 'civic' discourse highlights pluralism in society and sees the associative life as a guarantee of that. Tax incentives are then perceived as a condition for this associative dynamism and should be extended, for example, to all types of associations, to increase the means at their disposal:

Numerous sports clubs would have fewer problems if you could say, at the end of the year: 'Let's make a donation of 10,000 francs and we will then be able to deduct that from our taxes'. . . Maybe there is a person here and there who would really like to make a donation, because, in fact, it is very attractive if one can deduct it all.

(Interviewee 43, PLR)

Political actors with this frame also stress the fact that it is not desirable that all decision-making power and all means available for establishing social policies be concentrated in the state. They prefer 'bottom-up' initiatives, stemming from civil society, to the verticality of state power:

The state cannot be everywhere. This is not its role! . . Otherwise, we cannot escape; we find ourselves caught in the tentacles of an expanding state. . . A bit like in France, where, in fact, the system has become completely blocked because the state is ubiquitous. 
As for virtue, political actors with this frame agree on the fact that it is fair that those who give to good causes be recompensed and that the role of the state is to recognize and promote virtuous behavior. 'Civic' discourse is that which most emphasizes the virtuous nature of tax benefits.

This frame is that of a very heterogeneous group of political actors in terms of their party affiliation: we find amongst them as many political actors of the left as those of the right. Among the 16 political actors with this type of discourse, we find 8 from left-wing parties - one Parti ouvrier populaire (POP), three Parti socialiste (PS), four Greens, 4 from the center - one Parti évangélique suisse (PEV), three Parti démocrate-chrétien (PDC) - and 4 on the right - three Parti liberal-radical (PLR) and one Union démocratique du centre (UDC). These political actors are characterized by the fact that they are very committed to the world of associations and foundations. This commitment is an integral part of their identity: during interviews, they often refer to this, even before mentioning their political mandates. Particularly preoccupied by the difficulties encountered by small organizations (which they have generally observed in the context of their own involvement), they especially regret the administrative burden for the organizations incurred in the increased requirements of control, as well as the difficulties of recruiting volunteers. A number of them have, moreover, intervened in the political debate to ask for fiscal advantages for volunteers.

\section{Fiscal policies in favor of public-interest organizations, a means of reducing taxes and limiting the role of the state: the 'liberal' frame}

In the 'liberal' frame, the tax exemption of donations to philanthropic organizations is perceived, above all, as a means to limit public expenditures, taxes and state power. The common objective of these parliamentarians being 'a maximum reduction in taxes' (Interviewee 14, UDC), they consider, on the one hand, that the threshold of deductibility of donations is too low and, on the other hand, that it would be desirable to broaden the criteria of public-interest organizations: 'Yes, I would like to develop as many tax deduction schemes as possible. . . Every Swiss franc that is not controlled by the State is actually a gain' (Interviewee 31, UDC).

The 'liberal' frame combines different positive arguments from the categories of efficiency and democracy, as well as that of justice. Moreover, this is the only frame in which this category is drawn upon to favor tax incentives: the arguments which claim that 'a donation is another means of paying one's taxes, because it allows for the direct financing of social goods which the state will not be able to finance' and that 'the usual tax system is "confiscatory" and unjust, and anything which serves to alleviate this is good' are central. As one politician said: 'People give money, and then some of this money comes back into state coffers. For me this [is] absurd' (Interviewee 7, UDC).

This discourse focuses on the onerousness of the 'state bureaucracy': Philanthropic organizations are described as less expensive and more efficient than state services. The argument of tax competition is also more often drawn upon than in the other types of discourse, principally in raising the threat of major taxpayers going elsewhere.

These tax measures are also presented as a mechanism of direct democracy. They must permit 'the giving of greater liberty to individuals' (Interviewee 19, PLR) and are opposed to 'the optic of the left which considers that only policy or politics is capable of having the wisdom to know where to put the money' (ibid.). Tax even constitutes a danger: 'There is no longer individual responsibility. If worst comes to worst, it's communism! . . We trust the state, and then after there's shouting because they have to raise taxes' (Interviewee 7, UDC). 
This 'liberal' frame is particularly widespread on the right of the political chessboard. It is utilized by ten political actors, five of whom belong to the PLR and five to the UDC. They are generally not very involved in the third sector.

\section{Tax policies in favor of public-interest organizations, a measure of good management of public funds: the 'pragmatic' frame}

The 'pragmatic' frame presents tax exemptions for donations as a measure of good management and defends a 'moderate' approach in order to depoliticize the debate and avoid 'ideological postures'. The desire to find a 'happy medium' and avoid the 'extremes' generally translates into an attachment to the existence of a threshold of deductibility, even if the existing threshold is sometimes considered a little low.

Very clearly dominated by positive arguments from the value of efficiency, this frame is based, in particular, on two key arguments: 'you have to take the money where you find it' and 'the state alone cannot assume responsibility for every desirable policy'. Then, the idea of public-private complementarity often comes up as a 'common sense' position, 'to everyone's advantage'. The financing of public or para-public institutions (such as universities or hospitals) is often cited as an example:

Let's imagine that I win 20 million in the lottery. . . . If I were living in the canton of Baselland [a canton in which one may deduct up to 100\% of one's income], I could probably use this 20 million to serve a public interest organization without paying any tax. That could be the University of Basel, maybe with certain demands, like, for example: I would like this to be used in X or Y medical research. . . . In all the other cantons [where one can only deduct between 5 and 20\% of one's income] I could not do the same thing, because I would first have to pay taxes.

(Interviewee 38, PLR)

The predominance of the category of efficiency over other argumentative categories is expressed in the discourse through the demand for a 'utilitarian' stance: 'the goal is not to have greater fiscal justice ... ; it is only to have more donations', this justifying '[making] an exception to the principle of taxation based on the amount of income or fortune [and admitting] that this taxation could be somewhat reduced with the goal of encouraging grants and donations' (Interviewee 21, PLR).

While this frame is often critical of fiscal competition, it takes seriously the issue of 'attractiveness', in particular among members of cantonal executive bodies. Thus, a state councilor in charge of finances presents his mission as being a manager before being a politician: $\mathrm{He}$ explains that the dominant policy objective of tax exemptions is to 'maintain the tax substance' (Interviewee 8, PDC), that is, tax revenues, which he reminds us are dependent in large part on the wealthiest taxpayers. Proposing to these taxpayers advantages such as the possibility of deducting their philanthropic donations is a means of avoiding their departure for cantons with lower tax rates and at the same time allows the state to make substantial savings, since the third sector benefits from resources which allow it to carry out missions which would not be taken on by the public service. And, like those adhering to the 'civic' discourse, the 'pragmatic' ones think that tax incentives are a means of supporting dynamism in civil society and thus perceive them as inherently positive.

Parties from the center and the right, in particular the PLR, are overrepresented among those who adopt this discourse: among the 12 political actors with a 'pragmatic' frame, 7 are 
part of the PLR (the majority among them come from the former Radical Party), 2 from the PDC, 1 from the PBD, 1 from the PS and 1 from the Greens. This type of discourse is also most frequently heard, independently of party attachment, among political actors with executive responsibilities (cantonal ministers of finance), presidents/vice-presidents of tax commissions and members of the Council of States; these positions predispose them to adopt a discourse which puts 'the interest of the canton' in the forefront rather than the defense of a given political vision.

\section{Fiscal policies in favor of public-interest organizations, a risk factor for abuse and fraud: the 'wary' frame}

The 'wary' frame tends to present fiscal advantages for public-interest organizations as a risk: characterized by suspicion, it is focused on fraud, abuse and dysfunction. The criticism does not center on the principle of philanthropy or that of tax incentives in general but only on certain problematic aspects of the functioning of the third sector and of taxation. In this sense, the legislators whose discourse is of this type are not very interested in the question of the deductibility of donations and of the maximum thresholds for this.

Instead, they often turn their attention to 'scandals' of which they have become aware, and their remarks frequently take the form of commentary on the events of the day. For example, with respect to the risk of tax evasion:

What is very difficult in these questions is that they are not going to tell you the truth. It's true that tax evasion by means of foundations. . . . I question this. Still, there are some indications that prove that it's true. You tell me that they're obliged to say to whom they have donated but there can be some false statements; they can fiddle with the accounts. . . . Then, it's almost impossible to verify.

(Interviewee 45, PS)

This frame is essentially based on two negative arguments which belong to the categories of justice and of democracy: 'Deductions may be diverted from their purpose and used as an instrument of fiscal optimization' and 'Philanthropic organizations escape democratic control; their actions are not controlled or not controlled sufficiently by the political authorities'. This is maintained by a small number of political actors, gravitating around the center-left (one PS, one Greens, one PEV and one PDC). Two of them filed interventions against the exemption for major sports federations, developed in the particular context of the European Championship of football organized in Switzerland in 2008.

Finally, we will note that, while these politicians are very critical of abuses and question the criteria for recognizing public-interest organizations, they are rather reticent in terms of requiring more significant controls; in particular, they are afraid of the excess of the administrative work for the small associations. One explanation of this paradox can probably be found in the fact that these political actors divide the third sector into categories: for them, there are the 'good organizations' and, on the other side, the 'bad' ones. This division into good and bad is expressed in various ways by political actors, with other dualities, for example, large organizations vs. small ones or foundations vs. associations.

There are private law organizations where there is not even control of the surveillance of foundations. .. . So, while other organizations which are also tax exempt, like, for example, the railway museum in Zurich, of which I was the president until just 
last year. . . There, I also saw what the canton demands in order to receive this tax exemption. We have to report on everything that we earn with this steam locomotive, guarantee perfect accounting, everything must be invested, there is no compensation for the people who get up at 4 in the morning to warm up these steam locomotives and who return in the evening with a dirty face at any hour. . . That's different, ... there, that's perfectly alright. But in the case of organizations who operate as a kind of business, at the international level ..., that's problematic.

(Interviewee 1, PEV)

\section{Fiscal policies in favor of public-interest organizations, a vector of political, economic and social inequality: the 'critical' frame}

Finally, those who hold to the 'critical' frame are the only ones to condemn the fiscal measures encouraging philanthropy. For them, they constitute a violation of equality between individuals (rich and poor) and between organizations (those who can easily collect donations and those which defend less popular causes). Therefore, they are strongly opposed to political plans to increase the threshold of deductibility of donations or to extend the domain of public-interest organizations.

The 'critical' frame combines a multitude of negative arguments from each of the four categories. The concern with equality and universalism leads to criticism of the fact that the decisions of public-interest organizations escape democratic control:

Instead of paying taxes, you decide where the money goes; so, this contradicts the democratic principle. The democratic principle means that the public authority collects the money for the basics and decides on how much goes to schools, how much to roads, how much to hospitals.

(Interviewee 36, VE)

'Critical' discourse especially stresses tax losses due to tax exemptions and deductions - an issue relegated to the background in the other types of discourse:

Should we limit this? Yes, probably, because the canton's budget simply must be put in order. When there's nobody left to pay taxes because everyone. . . This is certainly not desirable.

(Interviewee 12, PS)

To criticize tax advantages, this discourse draws from the category of virtue, claiming that the failure to pay taxes is an immoral or unsociable act and that the principle of universality must be respected. However, it is interesting to observe that the 'critical' discourse does not go as far as to question the idea that 'the state on its own lacks the means to provide all desirable public and social services', which seems to be a view on which all agree.

This frame is that of a small number of politicians who all belong to parties of the left (four PS, one Greens and a POP) and are very active in the associative environment. Their position in the field of public-interest organizations (often close to umbrella organizations and association networks) and/or their experience with social work makes them more sensitive to questions related to financing and to the independence of associative structures. Quite isolated on these matters - including in their own parties - they deplore the fact that they are not understood by their colleagues, who, for lack of having invested sufficient time to grasp the profound political issues related to these technical fiscal questions, 'just don't get it' (Interviewee 36, VE). 


\section{Discussion: philanthropy, the product of an accumulation rather than a confrontation of arguments}

Examining the discourse of politicians allows us to show the way in which 'philanthropy' as a political object is constructed by the actors who legislate on the subject. These empirical results also lead us to enrich the theoretical literature on philanthropy and tax exemptions and to question a number of its assumptions, in particular with regard to two aspects: the rationales the discourses refer to and the role played by different representations of philanthropic organizations to explain variations in the way political actors frame tax exemptions for philanthropy.

In terms of rationales, the Swiss case shows the use of varied argumentation based on four rationales: fiscal justice, efficiency, democracy and virtue. While the first three rationales have been identified in other studies - Benshalom (2008) discusses efficiency (to encourage more and/or better spending of public goods) as well as civism or commitment (to allow taxpayers to express their preferences regarding the allocation of public goods in society), and Reich (2018) adds the question of tax justice - a fourth rationale appears in the comments of our interviewees. In this type of argumentation, the act of philanthropic giving as such is seen as inherently virtuous, and it is for this reason that it is seen as worthy of recognition and encouragement by the state. Contrary to the other rationales, which build on a broader general principle to which philanthropy contributes, the rationale of virtue recognizes the value of the act for itself.

The study also gives empirical insight into which rationales are used most often. It suggests that among the various rationales, efficiency is by far the most important, mobilized in all the identified discourses - well before those of democracy and justice. Philanthropy then seems to benefit from a more general trend - which goes beyond this single object - which sees politicians increasingly relying on purely economic concepts (Lebaron, 2013, p. 11; Weil, 2017) and which profoundly modifies the decision makers' perception and appreciation of social realities: efficiency rather than justice. But beyond this general trend, this finding also indicates that political actors apply the efficiency lens to a broader range of objects than what is commonly discussed in the literature. Most studies focus on the financial efficiency of tax incentives, but for many political actors, efficiency also relates to the greater capacity of philanthropic organizations to achieve their goals. If the discourse of efficiency occupies such a place, it is also because it mixes these two different dimensions which, as this study shows, are less seen as diverse and potentially contradictory than working together in favor of legal and fiscal reforms.

The second contribution of this study concerns the role of representations of philanthropic organizations for the frames political actors use to argue about it. The existing literature discusses the question of 'why fiscally encourage philanthropy'; the focus is on the distribution effects of tax exemption. Yet if we look at political actors' discourses, we see that beyond partisan cleavages on purported benefits of fiscal tools, their positions and arguments are very much related to the very heterogeneous depictions of philanthropy. As our interviews show, the ways of depicting philanthropy usually seem to be piecemeal and limited. This is as if, in the absence of established discourse on what this sector of public-interest organizations really is, each individual approached this through their own personal experience and with respect to their own preoccupations. This phenomenon is maybe particularly pronounced in the debates on public interest, because the third sector is an extremely plural one. It is composed of structures that are sometimes so different from one another that, strictly speaking, they do not have much in common. A great variety of organizations active in many different domains populate this sector in Switzerland: from small environmental NGOs to the Red Cross; from theater associations and local football clubs to huge international sports organizations like FIFA or UEFA, which are considered of public interest in Switzerland. 
The perception of the third sector and even the definition of public interest by Swiss politicians depend therefore widely on the type of organizations that they have in mind. The parliamentarians may or may not be involved in associations or foundations; some raise this question in thinking about donors, while others are thinking about the beneficiaries. When they think about these donors, some think about those who make monetary donations, while others, on the contrary, speak about those who give their time in volunteer activities. When they think about beneficiaries, some think of public and para-public establishments (such as universities or hospitals), others of small local associations, while still others make reference to the major international sports organizations. Some broached the subject because they were personally confronted with a practical incomprehension in the context of an involvement in public-interest organizations, while others interject following a media scandal or to make themselves the spokesperson for an association of public-interest organizations.

It is the way actors delimit the subject, in this case philanthropy, which matters when one wants to understand the positions taken and the frames used. The politicians adopting a 'wary' frame, for example, are not fundamentally opposed to tax incentives for philanthropy. They are simply interested, for one reason or another, in big international organizations and the supposedly negative effects of their fiscal advantages. Or, to take another example, the 'pragmatic' frame is mainly adopted by executive politicians at the cantonal level. When they speak of public interest, they think of organizations they encounter in their day-to-day work: During interviews, they speak of donations made for research but also of para-public organizations like regional home care services. Politicians embracing a 'civic' frame, on the other hand, are especially committed to the world of associations and foundations and are personally involved in the non-profit sector, mainly in small organizations. The lens through which they approach public interest as a political object is the concrete challenges encountered by these organizations and the strategies to facilitate their work.

In sum, while the literature often seems to confine the issue of philanthropy to the question of tax incentives for donations, our study shows, on the contrary, that when political actors think about philanthropy, they do not only think about donations (or donors) but just as much about philanthropic organizations, which are also tax exempt. Is it the fact that FIFA and UEFA have their headquarters in Switzerland? The question of their tax exemption is omnipresent, as is the comparison of their status vis-à-vis small sports clubs whose social utility seems no less important. As a counterpoint to a literature that most often focuses only on tax exemptions for donations, this study shows the extent to which, for political actors, the discussion on the legal and fiscal frameworks governing philanthropy concerns just as much - and even more importantly - the equity between organizations that benefit or not from these exemptions and the justification of these exemptions for such organizations.

\section{Notes}

1 The authors would like to thank the attentive reviewers of a previous version of this chapter for their insightful comments.

2 The term 'philanthropy' does not have a legal definition in Swiss law. Regarding direct taxes, Swiss federal law exempts legal entities that are pursuing public-service or public-interest purposes from the federal income tax on profits that are exclusively and irrevocably affected to such purposes (Art. 56 lit. 6 LIFD) and allows donations in favor of these entities to be deducted of income (or net profit) up to a maximum of $20 \%$ (Art. 33a and 59 let. c LIFD). In the present analysis, the term 'philanthropy' is used in its two possible linguistic meanings, that is, regarding the taxation of 1) philanthropic organizations and of 2) philanthropic transfers of funds or other property (donor taxation). 


\section{Honegger, Carnac, Balsiger and Lambelet}

3 Regarding direct taxes, Switzerland exempts legal entities that have: 1) purpose of general interest, 2) unlimited circle of beneficiaries, 3) exclusive and irrevocable contribution of the funds, 4) disinterest and 5) actual non-profit activity.

4 We focused on the parliamentary activity of three cantons in particular: Geneva, Neuchâtel and Baselland. These three cantons were chosen due to different limits on the deductibility of donations which they adopted or modified in the 2000s (5\% of taxable income or profits in Neuchâtel, $20 \%$ in Geneva and no limit in Baselland).

5 For a detailed list of the interviewees and their interventions, we refer the reader to Lambelet et al. (2021). We indicate here the political party of the interviewees using party acronyms. Switzerland has a multiparty system whose political parties can be categorized in three groups. Parties of the left: POP (Parti ouvrier et Populaire [Swiss Labour Party]), PS (Parti socialiste [Social Democratic Party]), VE (Les Verts [Green Party]). Parties of the centre: PDC (Parti démocrate-chrétien [Christian Democrats]), PEV (Parti évangélique [Evangelical People’s Party]), PBD (Parti bourgeois-démocratique [Conservative Democratic Party]). Parties on the right: PLR (Parti libéral-radical [The Liberals]), UDC (Union démocratique du centre [Swiss People's Party]).

6 In contrast with the long US tradition of making public financial forms and annual reports, Swiss foundations have to report only to the state supervisory authority, which does not make the information public (Schnurbein and Perez, 2018).

\section{References}

Ariely, D., Bracha, A. and Meier, S. (2009). 'Doing good or doing well? Image motivation and monetary incentives in behaving prosocially'. American Economic Review, 99(1), pp. 544-555.

Bakija, J. and Heim, B. T. (2011). 'How does charitable giving respond to incentives and income? New estimates from panel data'. National Tax Journal, 64(2, Part 2), pp. 615-650.

Bekkers, R. and Wiepking, P. (2011). 'A Literature Review of Empirical Studies of Philanthropy: Eight Mechanisms That Drive Charitable Giving'. Nonprofit and Voluntary Sector Quarterly, 40(5), pp. 924-973.

Benshalom, I. (2008). 'The Dual Subsidy Theory of Charitable Deductions'. Indiana Law Journal, 84, pp. 1047-1097.

Best, J. (2008). Social Problems (1st ed.). New York, NY: W.W. Norton \& Company.

Brilliant, E. (2000). Private Charity and Public Inquiry: A History of the Filer and Peterson Commissions. Bloomington, IN: Indiana University Press.

Cagé, J. (2020). The Price of Democracy: How Money Shapes Politics and What to Do About It. Cambridge, MA: Harvard University Press.

European Foundation Center. (2015). Comparative Highlights of Foundation Laws. Bruxelles: EFC.

Gamson, W.A. and Modigliani, A. (1989). 'Media Discourse and Public Opinion on Nuclear Power: A Constructionist Approach'. American Journal of Sociology, 95(1), pp. 1-37.

Goffman, E. (1974). Frame Analysis: An Essay on the Organisation of Experience. New York, NY: Harper.

Helmig, B., Gmür, M., Bärlocher, Ch., von Schnurbein, G., Degen, B., Nollert, M., Wojciech Sokolowski, S. and Salamon, L. (2017). 'Switzerland: A Liberal Outlier for Europe'. In Explaining Civil Society Development: A Social Origins Approach. Baltimore, MD: Johns Hopkins University Press, pp. 131-142.

Helmig, B., Lichtsteiner, H. and Gmür, M. (2010). Der Dritte Sektor der Schweiz: die Schweizer Länderstudie im Rahmen des Johns Hopkins Comparative Nonprofit Sector Project (CNP) (1. Auf.). Bern: Haupt Verlag.

Howard, Ch. (1993). 'The Hidden Side of the American Welfare State'. Political Science Quarterly, 108(3), pp. 403-436.

Krippendorff, K. (2004). Content Analysis: An Introduction to Its Methodology (2nd ed.). Thousand Oaks, CA: Sage.

Lambelet, A. (2014). La Philanthropie. Paris: Presses de Sciences Po.

Lambelet, A., Balsiger, P., Carnac, R. and Honegger C. (2021). Reconnaître l'utilité publique. Parlementaires et personnel des administrations fiscales face à la philanthropie en Suisse. Lausanne: HETSL Editions.

Layton, M. (2015). 'The Influence of Fiscal Incentives on Philanthropy Across Nations'. In Wiepking, P. and Handy, F. (eds). The Palgrave Handbook of Global Philanthropy. London: Palgrave Macmillan, pp. 540-557.

Leat, D. (2016). Philanthropy Foundations, Public Good and Public Policy. London: Palgrave Macmillan.

Lebaron, F. (2013). 'Pour une sociologie de la production et de la diffusion des discours économiques: Réflexion à partir de l'exemple de la notion de modèle social'. In Temmar, M., Angermüller, J. and Lebaron, F. (eds). Les discours de l'économie. Paris: Presses Universitaires de France, pp. 13-32. 
Lideikyte Huber, G. (2018). 'Philanthropy and Taxation: Swiss Legal Framework and Reform Perspectives'. Expert Focus, 3, pp. 209-213.

Lideikyte Huber, G. (2020). 'Tax Incentives for Charitable Giving as a Policy Instrument: Theoretical Discussion and Latest Economic Research'. World Tax Journal, 12, p. 3.

McDaniel, P.R. (1989). ‘Tax Expenditures as Tools of Government Action'. In L.M. Salamon (ed). Beyond Privatization: The Tools of Government Action. Washington, DC: The Urban Institute Press, pp. 167-195.

McGravie, M. (2003). 'The Dartmouth College Case and the Legal Design of Civil Society'. In Friedman, L. and McGravie, M. (ed). Charity, Philanthropy and Civility in American History. New York, NY: Cambridge University Press, pp. 91-105.

Monnet, N. and Panizza, U. (2017). A Note on the Economics of Philanthropy. IHEID Working Papers No. 19. Genève: Economics Section, The Graduate Institute of International Studies.

OECD. (2020). Taxation and Philanthropy. OECD Tax Policy Studies No. 27. Paris: OECD Publishing. https://doi.org/10.1787/df434a77-en

Reese, S.D., Gandy, O. and Grant, A.E. (eds). (2001). Framing Public Life: Perspectives on Media and Our Understanding of the Social World. New York, NY: Routledge.

Reich, R. (2013). 'Philanthropy and Caring for the Needs of Strangers'. Social Research: An Internal Quarterly, 80(2), pp. 517-538.

Reich, R. (2018). Just Giving: Why Philanthropy Is Failing Democracy and How It Can Do Better. Princeton, NJ: Princeton University Press.

Reich, R., Cordelli, C. and Bernholz, L. (eds). (2016). Philanthropy in Democratic Societies: History, Institutions, Values. Chicago and London: University of Chicago Press.

Saez, E. and Zucman, G. (2019). The Triumph of Injustice: How the Rich Dodge Taxes and How to Make Them Pay. New York, NY: W.W. Norton \& Company.

Salamon, L.M. (1989). 'The Changing Tools of Government Action: An Overview'. In Salamon L. (ed). Beyond Privatization: The Tools of Government Action. Washington, DC: The Urban Institute Press.

Salamon, L.M. and Anheiner, H.K. (1998). 'Social Origins of Civil Society: Explaining the Nonprofit Sector Cross-Nationally'. Voluntas: International Journal of Voluntary and Nonprofit Organizations, 9(3), pp. 213-248.

Salamon, L.M. and Toepler, S. (2000). The Influence of the Legal Environment on the Development of the Nonprofit Sector. Working Paper Series No. 17. Baltimore, MD: The Johns Hopkins University Institute for Policy Studies/Center for Civil Society Studies.

Schnurbein von, G. and Perez, M. (2018). 'Foundations in Switzerland: Between the American and the German Cases'. American Behavioral Scientist, 62(13), pp. 1919-1932.

Steinmo, S. (1986). 'So What's Wrong with Tax Expenditures? A Reevaluation Based on Swedish Experience'. Public Budgeting \& Finance, 6(2), pp. 27-44.

Thaler, R. H. (2010). 'It's Time to Rethink the Charity Deduction'. The New York Times, 18 December.

Weil, S. (2017). 25 Jahre New Public Management in der Schweiz. Zehn Gestalter erzählen. Cahier de l'IDHEAP. Cahier de l'IDHEAP 300. Lausanne: IDHEAP.

Zunz, O. (2011). Philanthropy in America: A History. Princeton, NJ: Princeton University Press. 